\title{
Changing fire regimes and faunal responses: Habitat use by Flammulated Owls after fire in Colorado
}

\author{
Scott W. Yanco ${ }^{1,2, *}$ and Brian D. Linkhart ${ }^{1}$
}

\begin{abstract}
Since European settlement, human activities have resulted in fires that have burned the pine forests of western North America at higher severity and over larger areas than previously. On the basis of global climate models and current fuel loading across the West, larger and more severe fires are predicted to become more common in the future. Despite the potentially severe consequences of such fires on landscape structure and function, the effects of altered fire regimes on the behavior and ecology of birds in western forests have been little studied. We sought to determine how the Hayman Fire, which burned the largest area $\left(560 \mathrm{~km}^{2}\right)$ in Colorado history in 2002, affected habitat selection at multiple spatial scales by Flammulated Owls (Psiloscops flammeolus) that recolonized the burned area from 2003 to 2012. We radiotracked five breeding male owls from 2007 to 2012 and quantified their patterns of habitat use at multiple spatial scales. Breeding males established home ranges in habitats containing less area burned at high severity and more area burned at low severity or remaining unburned than was available within the fire's entire perimeter. Additionally, the size of a home range was positively correlated with the proportion of area burned at high severity, indicating that such areas represent low-quality habitat for the species. The level of burn severity did not appear to be an important factor in the selection of habitats for foraging or day-roosting, indicating that habitat-selection patterns were altered by fire only at the scale of the home range. Our findings suggest that species with life histories highly adapted to ecosystems dependent on fire of low or mixed severity may not be resilient to human-modified fire regimes in which the proportion and patches of forest burned at high severity are larger. As the area burned at high severity increases, more western forests may become unsuitable for occupancy by species that have otherwise evolved with naturally occurring low-severity fire.
\end{abstract}

Keywords: disturbance, burn severity, home range, pine forest, Pinus ponderosa, radio-telemetry, spatial scale, wildfire

A cross western North America, patterns of fire frequency, severity, and size are generally correlated with latitude, elevation, and floristic composition (Veblen et al. 2000, Brown and Shepperd 2001, Romme et al. 2003). At lower elevations and latitudes, forests dominated by pines (Pinus spp.) experienced frequent (every 5-30 years) fires of low severity. These typically consumed small trees, shrubs, and herbaceous growth, and promoted the maintenance of open forests containing clumps of larger, older trees (Covington and Moore 1994, Veblen et al. 2000, Brown and Shepperd 2001). Conversely, forests at higher elevations and latitudes typically experienced less frequent fires (every 100-400 years), and the relatively mesic conditions and low decomposition

rates in these forests promoted the build-up of fuels between fires (Brown and Shepperd 2001, Schoennagel et al. 2004). Increased fuel loads, coupled with higher forest densities in these environments, resulted in fires that were generally stand-replacing (Brown and Shepperd 2001, Schoennagel et al. 2004).

Between these extremes, mixed-conifer forests at intermediate elevations and latitudes experienced fires of mixed severity every 30-100 years, resulting in a mosaic of patches burned at various severities across the landscape (Brown et al. 1999, Kaufmann et al. 2003, Romme et al. 2003). These mixed-severity fires typically burned heterogeneous environments encompassing a range of elevations, aspects, and dominant cover types

Full citation: Yanco, S. W., and Linkhart, B. D. 2018. Changing fire regimes and faunal responses: Habitat use by Flammulated Owls after fire in Colorado, in Trends and traditions: Avifaunal change in western North America (W. D. Shuford, R. E. Gill Jr., and C. M. Handel, eds.), pp. 419-431. Studies of Western Birds 3. Western Field Ornithologists, Camarillo, CA; doi 10.21199/SWB3.22.

${ }^{1}$ Colorado College, Department of Organismal Biology and Ecology, 14 E. Cache La Poudre, Colorado Springs, Colorado 80903 , 2Present address: University of Colorado Denver, Department of Integrative Biology, P.O. Box 173364, Denver, Colorado $80217-$ 3364; *corresponding author: scott.yanco@ucdenver.edu 
(Romme et al. 2003, Schoennagel et al. 2004). In Colorado's Front Range, for example, northfacing slopes typically support denser and more mesic forests, which burn at higher severities, whereas south-facing slopes typically support less dense and more xeric forests, which burn at lower severities.

While the effects of all fire regimes on ecosystem function are important to understand, fires of low and mixed severity are particularly important because they have strongly influenced the evolution and ecology of ponderosa pine (P. ponderosa) and mixed conifer forests that are widespread across western North America (Covington and Moore 1994, Allen et al. 2002, Abella et al. 2007). Ponderosa pines exhibit adaptations common to many pine species that evolved with frequent low-severity fire, including thick "fire-resistant" bark and self-pruning of lower limbs (Binkley et al. 2007). Several species of animals that inhabit dry pine forests are also adapted to environments maintained by low- and mixed-severity fires (e.g., Conway and Kirkpatrick 2007, Hutto 2008, Davis et al. 2012). For example, the Pygmy Nuthatch (Sitta pygmaea) prefers habitats (widely spaced stands of large, old ponderosa pines) that are mediated by frequent fires of low severity (Szaro and Balda 1982, Brawn and Balda 1988).

Since European settlement, across western North America, a greater proportion of dry pine-dominated forests has burned at higher severity (greater crown mortality) than occurred previously (Huckaby et al. 2001, Kaufmann et al. 2001, Fulé et al. 2014). Primary factors that have contributed to this trend include logging, overgrazing, and fire suppression, all of which have led to a prevalence of young stands of trees of the same age, increased fuel loads and stand densities, and more continuous canopy cover (Veblen et al. 2000, Miller et al. 2009, Fulé et al. 2014). These changes in forest structure have resulted in an increase in the extent and severity of fires in many coniferous forests, including those in Colorado's Front Range, formerly characterized by a regime of fires of low or mixed severity, (Covington and Moore 1994, Kaufmann et al. 2001, Sherriff et al. 2014).

In addition, climate change has been further modifying fire regimes across western North America. Total biomass burned and the extent and frequency of wildfires are strongly correlated with regional climate patterns (Westerling et al. 2006, Marlon et al. 2012), and increasingly hot and dry conditions are driving wildfires to burn larger areas at higher severities (Westerling et al.
2006). Given current predictions for the climate (IPCC 2013), western forests are expected to experience modified fire regimes different from the historical norms well into the future (Running 2006, Hurteau et al. 2014, Rocca et al. 2014, Sherriff et al. 2014).

Historically, regimes of low- and mixed-severity fire acted as important drivers of landscape heterogeneity by leaving a structurally variable landscape where the forest's overstory was left intact in some areas and experienced 100\% mortality in others (Kaufmann et al. 2003, Williams and Baker 2012, Odion et al. 2014). The recent trend toward stand-replacing fires at the landscape scale has homogenized forest structure by promoting recruitment of cohorts of even-aged trees over large areas (Covington and Moore 1992, 1994, Allen et al. 2002, Fulé et al. 2003). These support lower overall biodiversity than do structurally diverse forests (Allen et al.1998) and may no longer support the same fauna as they did previously (USGAO 1999, Westerling et al. 2011).

Despite the extent to which fire regimes of western forests are being modified, few studies have focused on faunal responses to such changes. Recent research has indicated that avian responses to fire may be influenced by foraging behavior, as evidenced by a positive correlation between the relative abundance of species within particular guilds and the availability of preferred foraging habitats following fire (Kotliar et al. 2007). Still, there is a lack of information on how breeding birds adapted to low- or mixed-severity fire regimes use burned landscapes when establishing home ranges and selecting habitats for foraging and roosting, particularly where fire regimes have been anthropogenically modified. The manner in which animals use habitats may influence their demographic performance (e.g., Breininger et al. 1994, Linkhart and Reynolds 2006) and affect species' interactions across trophic levels (e.g., Schmitz et al. 1997, Fagan et al. 1998). A better understanding of avian responses to fire is critical to illuminating how processes at the levels of the population, community, and ecosystem may be affected by changing fire regimes.

We sought to determine how the 2002 Hayman Fire, which burned the largest area in Colorado history (Graham 2003), affected habitat selection at multiple spatial scales by breeding Flammulated Owls (Psiloscops flammeolus) from 2003-2014. The Flammulated Owl is a small migratory raptor that breeds from southwestern Canada through the western United States to central Mexico (Linkhart and McCallum 2013), where it tends to 
prefer older stands of ponderosa pine and Douglas fir (Pseudotsuga menziesii; Linkhart et al. 1998, Linkhart and Reynolds 2006, 2007), and winters from northern to southern Mexico (Linkhart et al. 2016). It is considered a "sensitive species" by the U.S. Forest Service in Regions 1, 2, and 4 (USFS 2004), a national "bird of conservation concern" by the U.S. Fish and Wildlife Service (USFWS 2008), and a "species of special concern" in Canada (COSEWIC 2010). Donovan et al. (2002) also identified the owl as a priority species for assessing effects of habitat alteration in western forests. Currently, data concerning the owl's use of habitats in areas subjected to altered fire regimes are lacking.

Our objectives were to (1) describe the size, shape, and juxtaposition of the home ranges of Flammulated Owls within the area burned in the Hayman Fire; (2) compare patterns of burn severity within the owls' home ranges to those of the entire burned area; and (3) compare habitat variables (including burn severity) of foraging and day-roosting sites to available habitat within home ranges. We predicted that owls should prefer unburned or low-severity burned habitats at all spatial scales, because of those habitats' resemblance to unburned forests, where Flammulated Owls preferentially establish territories and forage in areas containing older stands of ponderosa pine and Douglas-fir (Linkhart et al. 1998).

\section{Study AREA ANd Methods}

We conducted our study in the Pike National Forest in central Colorado, within the eastern portion of the area burned by the Hayman Fire in 2002 (Figure 1). This fire burned approximately $560 \mathrm{~km}^{2}$ (Graham 2003), of which nearly 50\% burned at high severity; the historic norm for this area is $-20 \%$ (Romme et al. 2003). Before the fire, forests in our study area were typically dominated by open stands of mature (100- to 200-year-old) and old growth (>200-year-old) ponderosa pines on south-facing slopes, ridgetops, and flat areas, and denser stands of younger (largely $<100$-yearold) ponderosa pines, with some mature stands of Douglas-fir/ponderosa pine, on north-facing slopes (Finney et al. 2003). Drainage bottoms were dominated by quaking aspen (Populus tremuloides) or quaking aspen/blue spruce (Picea pungens; Finney et al. 2003). Elevations within the study area range from 2300 to $2600 \mathrm{~m}$. Mean temperatures from 1981 to 2010 were 18.7 ${ }^{\circ} \mathrm{C}$ from June to August and $-1.4{ }^{\circ} \mathrm{C}$ from December to February (NOAA 2010). Mean annual precipitation was $40.3 \mathrm{~cm}, 60 \%$ of which fell from May to September (WRCC 2015).

\section{BURN-SEVERITY ANALYSIS}

The Hayman Fire burn area exhibited a mosaic of severities, which we defined according to the proportion of dominant/canopy trees that were killed: high severity, areas where $>90 \%$ were killed; moderate severity, areas where $5-90 \%$ were killed; and low severity, areas where $<5 \%$ were killed (sensu Key and Benson 2006; Figure 2). The highest burn severities within the Hayman Fire generally occurred in areas containing greater amounts of fuels and more continuous canopies (typically on north- and east-facing slopes), whereas fires of lower severity were commonly associated with south- and west-facing slopes (Romme et al. 2003). While burn severity in drainage bottoms was variable, most quaking aspens were killed by the fire's heat but were not combusted.

Using Landsat 7 imagery from the U.S. Geological Survey from 2000 (pre-fire) and 2005 (post-fire), we generated fire-severity maps by calculating the change in normalized difference vegetation index ( $\delta$ NDVI). We calibrated $\delta$ NDVI values to field-calculated composite burn indices (CBI) for focal trees by linear regression, and we used a CBI threshold of 1.0 for low to moderate severity and 2.0 for moderate to high severity (Key and Benson 2006). We then used $\delta$ NDVI values that corresponded to the CBI thresholds as cutoffs within the $\delta$ NDVI raster data to assign all $\delta$ NDVI pixels within the study area to one of three burnseverity classes, defined a priori: low severity or unburned, moderate severity, or high severity (Figures 1 and 2). The raster data were clipped to a pre-defined outline of the Hayman Fire provided by the U.S. Forest Service (unpubl. data), which encompassed approximately 93,250 ha, including unburned enclaves and other features, such as open water.

\section{LOCATION OF \\ OWL TERRITORIES AND NESTS}

We surveyed the eastern portion of the area burned in the Hayman Fire for occupancy by Flammulated Owls in June and July of 2003, 2004, and 2005 by 5 -minute point counts (Bibby et al. 1997) at $0.8-\mathrm{km}$ intervals along passable roads. In areas where we detected territorial males, we used spot mapping (Bibby et al. 1997) to delineate boundaries of home ranges, which are synonymous with territories since the owls defend type I territories (where all breeding behaviors occur within a defended area; Hinde 1956, 


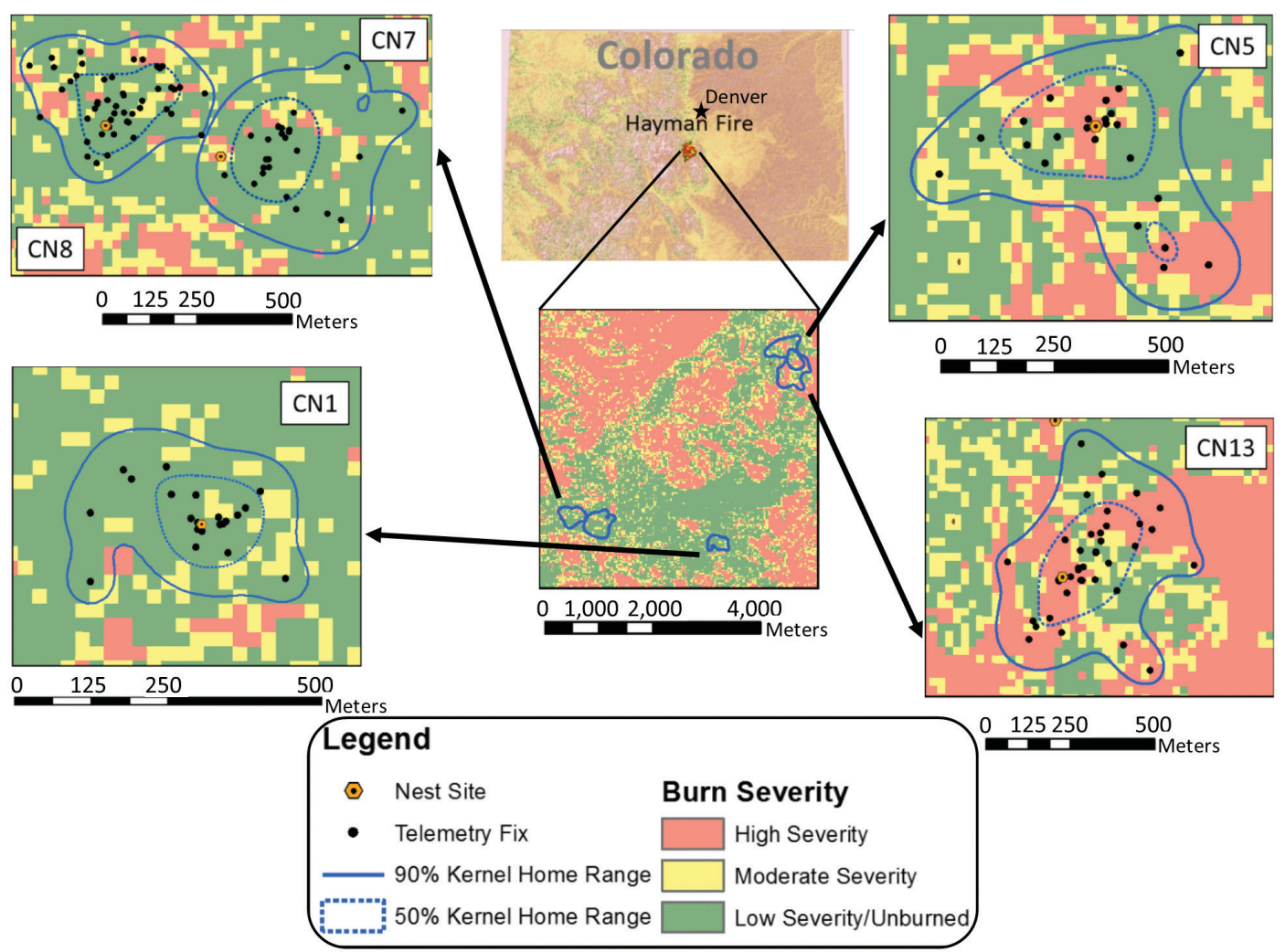

FIGURE 1. Location of home ranges of five male Flammulated Owls assessed from 2007-2012 within the area burned by the Hayman Fire in Colorado in 2002. For each male, the $90 \%$ kernel home range and $50 \%$ core area boundaries, raw telemetry fixes, and nest site are shown relative to the maps of burn severity based on the normalized difference vegetation index $(\delta \mathrm{NDVI})$.

Linkhart et al. 1998). We mapped home range boundaries in ArcGIS 10.1 (ESRI 2012).

We searched for nests during the incubation (late May-late June) and nestling phases (late June-late July) from 2004 to 2014 by listening for females' food-solicitation calls at night in portions of territories containing tree cavities (Reynolds and Linkhart 1984). In addition, we systematically checked tree cavities for occupancy during the day by tapping trees to induce females to rise to cavity entrances, and we also examined cavities' contents with cameras mounted on telescopic poles.

\section{RADIO TELEMETRY}

We used radio transmitters from Advanced Telemetry Systems (model A1030, Isanti, MN), which had a battery life of 40 days, and we detected signals at distances up to $1 \mathrm{~km}$. We affixed transmitters to owls during the incubation and nestling phases by means of a backpack harness constructed from flexible Lycra straps and quick-drying glue (Reynolds and Linkhart 1984).
Radio transmitters weighed $1.9 \mathrm{~g}$ each, and the total weight with harness was $-2.5 \mathrm{~g}(-4.7 \%$ of a male's average body mass). For radio tracking we used a hand-held receiver (model R-1000, Communication Specialists, Orange, CA) and a three-element Yagi antenna.

During nocturnal tracking, we traveled on foot to track individual males to specific trees, which we identified by searching for the strongest transmitter signal from multiple locations surrounding a tree where we suspected an owl. We recorded a tree as a "fix" when we acquired an equally strong signal from multiple angles around a tree. We then attempted to assign a male's behavior (foraging, resting, or singing) on the basis of observation aided by headlamp or silhouette against the sky. If the owl could not be seen, researchers listened at the tree for $-1-15$ minutes and attempted to assign behavior by aural cues. We had no indication that the owls' behavior was directly affected by the presence or activities of the observer. We categorized the male's behavior as foraging if a foraging attempt was observed or if wing flaps 


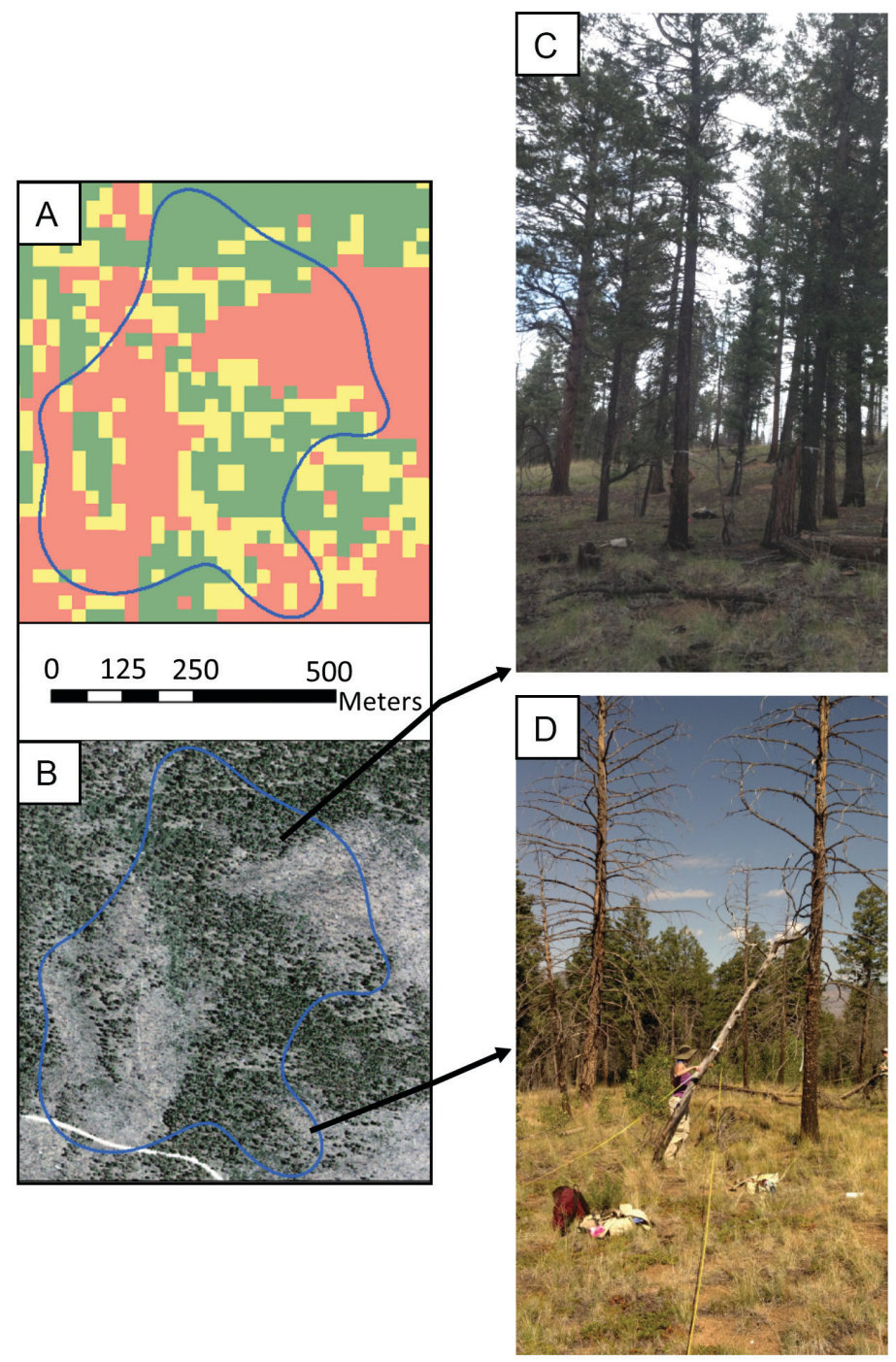

FIGURE 2. Habitat in the home range of one Flammulated Owl (male CN13) within the area burned in 2002 in the Hayman Fire in Colorado. (A) Map of burn severity based on the normalized difference vegetation index ( $\delta \mathrm{NDVI}$ ) with $90 \%$ kernel home-range boundary in blue; (B) aerial imagery with $90 \%$ kernel home-range boundary in blue; and, examples of (C) a low-severity burned site (composite burn index $[\mathrm{CBI}]=0.1$ ) and (D) a high-severity burned site $(\mathrm{CBI}=2.63)$ within the home range. Arrows from (B) to (C) and (D) indicate approximate photo locations. observers were able to get close to a male's location but could not identify the specific tree as a fix, then we recorded a "general area" fix, which we used only for calculating the bird's home range. We recorded each location by means of a hand-held global positioning system (GPS) unit and, if applicable, marked trees with flagging.

Between 2007 and 2012, we radio-tracked five different breeding males, including two males tracked in consecutive years (2007-2008), over a total of 49 hours during June and July (corresponding to the incubation and nestling phases). In 2007, we tracked two males for 10 hours; in 2008, the same two males for 14 hours; in 2009, one male for 5.5 hours; in 2010, one male for 7 hours; and in 2012, one male for 12.5 hours. Nocturnal tracking typically began shortly after sunset (20:20-20:45) and continued up to 00:30. We recorded a total of 162 fixes, $19 \%$ of them from $20: 00$ to $20: 59,28 \%$ from $21: 00$ to $21: 59,33 \%$ from $22: 00$ to $22: 59,16 \%$ from $23: 00$ to 23:59, and $4 \%$ from $00: 00$ to 00:30. Approximately 23\% (37) of all fixes were recorded during the incubation phase and $77 \%$ (125) during the nestling phase.

\section{HOME-RANGE ANALYSIS}

We quantified owls' home ranges by using the minimum-convexpolygon (MCP) method and kernel-density estimates (KDE). We delineated MCP boundaries in ArcGIS 10.1 (ESRI 2012) and calculated KDE rasters and against foliage were heard. We also stationed additional observers at nests, and we used observations of a radio-tagged male delivering prey to his nest immediately following a report of a fix (via two-way radios) as confirmation of foraging. We categorized behavior as singing if territorial song was heard in the immediate vicinity and as resting in the absence of the above cues. We also attempted to locate trees in which males roosted by day, but this was typically done diurnally. If isopleths in Geospatial Modeling Environment 0.7.2.1 (Beyer 2012), which requires the integrated platform of ArcGIS 10.1 and program R (R Core Team 2014). We produced $90 \%$ and $50 \%$ kernel isopleths, which estimated the owls' home ranges and core areas, respectively. We used likelihood cross-validation to determine the kernels' smoothing parameters (sensu Horne and Garton 2006), and we set the grid cells at $30 \mathrm{~m} \times 30 \mathrm{~m}$ to match the resolution of the Landsat Imagery 
used for burn-severity analysis. Fixes recorded during extra-territorial movements were not used in delineation of home ranges but were included in modeling of foraging-tree selection. We also excluded fixes recorded after fledging, given that home-range boundaries break down after this time (Linkhart et al. 1998). We calculated the home ranges of the two males tracked in consecutive years with fixes from both years combined because (1) males' site fidelity in unburned forest is high (Linkhart and Reynolds 2007) and (2) the spatial distribution of fixes recorded for those two males was similar in both years, including reuse of the same nest site.

Using ArcGIS, we calculated the proportion of home ranges estimated by MCP and of home ranges and core areas estimated by kernel density, that burned at the various severities, and compared these to the same proportions available within the entire area burned in the Hayman Fire. We excluded from this analysis $\delta$ NDVI raster cells $(30 \mathrm{~m} \times 30 \mathrm{~m})$ that overlapped home-range and/or kernel core-area boundaries when centers of cells were outside home-range or core-area polygons.

\section{MiCRO-SITE HABITAT QUANTIFICATION}

Within home ranges, we quantified habitat used by owls for breeding behaviors at a finer scale. We defined the micro-site as the particular tree used by the owl for foraging or day-roosting and the forest stand as the area within $\mathrm{a} \sim 10$-m radius of the tree.

\section{Foraging and Roosting Habitat}

We quantified the habitat associated with fixes of foraging and day-roosting in July 2012. To assess whether micro-sites of foraging were important factors in habitat selection, for trees where an owl was foraging (focal trees), we identified the tree as live or dead, its species, its diameter at breast height (dbh), its height (assessed with a clinometer), and its crown volume (program HTVOL; Mawson et al. 1976), and compared these variables to available but unused trees. We used the same habitat-quantification regime for day-roosting micro-sites. We quantified variables in the forest stand immediately surrounding foraging and day-roosting trees by the point-quarter method (Cottam and Curtis 1956), where we recorded the slope position, aspect, grade, canopy closure, ground cover, and CBI, as well as the same suite of characteristics as the focal tree for the nearest neighboring tree in each quadrant according to two size classes $(\geq 20 \mathrm{~cm}$ dbh and $<20 \mathrm{~cm}$ $\mathrm{dbh}$ ), and we compared these characteristics to randomly selected but unused sites.

\section{DATA ANALYSIS}

We analyzed selection patterns in foraging and day-roosting sites with a Bayesian generalized mixed-effects model (with non-informative priors) under an information-theoretic framework. To account for pseudoreplication, we included territory identification as a random effect in all models. Predictor variables correlated at $r>0.6$ were not included together in models. Because of our small sample size, we did not consider any models with more than two predictor variables (except for categorical "dummy" predictors such as species of focal tree). Continuous predictors were centered and scaled by the method of moments to account for non-normal distributions. Predictor variable distributions were assessed in program $\mathrm{R}$ (R Core Team 2014) by means of the package "fitdistrplus" (Delignette-Muller and Dutang 2015). Hypothesized models were generated a priori on the basis of our previous experience with the Flammulated Owl and published literature. We used the "widely applicable information criterion" (WAIC; Watanabe 2010) to distinguish among models and evidence ratios $(\mathrm{ER}=\Sigma$ model weights $_{\text {with parameter }} / \Sigma$ model weights without parameter $)$ to assess the degree of support for particular variables given the set of candidate models.

We fitted models and associated statistics in program R (R Core Team 2014) by using the function "map2stan" in the package "rethinking," which uses RStan for fitting of models. We calculated descriptive statistics in program $\mathrm{R}$ and Microsoft Excel (2013). We present all values as means and 95\% confidence intervals, calculated by nonparametric bootstrapping, unless otherwise stated.

\section{RESULTS}

\section{HOME RANGE}

We recorded a mean of 23 (range 13-40) fixes per male per year for five breeding males from 2007 to 2012, including two males (CN7 and CN8) tracked in consecutive years. Seventy percent (114 of 162) of fixes were attributed to specific behaviors, and, of these, foraging was the most frequently observed $(n=59 ; 61 \%)$, followed by day-roosting $(n=22 ; 19 \%)$, territorial singing $(n=$ $18 ; 16 \%)$, resting $(n=12 ; 11 \%)$, and other $(n=3$; $3 \%)$. The mean size of a home range as estimated by the $90 \%$ kernel (19.4; range 8.7-29.0 ha) was $-50 \%$ larger than that estimated by MCP (12.9; 
range 4.9-23.4 ha; Figure 1). All home ranges encompassed at least one drainage bottom, where nests were typically located, and one or more ridge slopes and ridgetops, the latter frequently serving as common boundaries between adjacent home ranges (Figure 1). Qualitatively, we recorded most territory songposts along home-range boundaries shared among multiple males, and few where conspecific neighbors were absent. Four of five home ranges had a single kernel core area (mean 4.3, range $0.4-7.5 \mathrm{ha}$ ), whereas one had two core areas (CN5; Figure 1). Core areas represented on average $27 \%$ of kernel home ranges (range $24-32 \%$ ).

Measures of $\delta$ NDVI were reliably calibrated to field-calculated CBIs, which reflected moderately high correlation between the two metrics $(r=0.47, p<0.001)$, and CBIs of 1.0 and 2.0 (thresholds for low-to-moderate and moderateto-high severities) corresponded to $\delta$ NDVI values of -0.07 and -0.12 , respectively. The MCP and kernel-estimated home ranges contained substantially less forest burned at high severity (mean across all territories $24.4 \%$ and $22.8 \%$, respectively) and more low-severity burned or unburned forest (mean across all territories 51.9\% and $56.6 \%)$. In comparison, within the Hayman Fire's perimeter as a whole, $48.7 \%$ of the forest burned at high severity, $33.6 \%$ at low severity or remained unburned (Figure 1). The mean proportions of the owls' home ranges burned at moderate severity were $23.7 \%$ (by MCP) and $20.6 \%$ (by kernel density), whereas within the Hayman Fire's perimeter as a whole that proportion was $17.7 \%$. In one territory (CN13), $44.7 \%$ of the forest was burned at high severity, but this area likely was overestimated by the $\delta$ NDVI, as evidenced by the CBIs implying fire at low or moderate severity for most use sites (mean $1.1 \pm 0.2$ ), despite the majority of these sites lying in areas mapped as burned at high severity by the $\delta$ NDVI raster (Figure 1). Paralleling the pattern shown by most home ranges, kernel core areas contained a mean of $26.3 \%$ high-severity burned forest and $56.8 \%$ low-severity burned forest (Figure 1). Both the MCP and kernel estimates of home-range size trended toward a positive correlation with the proportion of area burned at high severity $(r=0.87, p$ $=0.06$ and $r=0.87, p=0.06$, respectively).

\section{FORAGING HABITAT}

Foraging fixes were most commonly recorded in unburned or low-severity burned forest (mean $\mathrm{CBI}=0.78 ; 95 \% \mathrm{CI}=0.53-1.05)$, and no foraging fixes were recorded in areas burned at high severity $(\mathrm{CBI}>2.0)$. We recorded a mean of 11.8 (range 1-16) foraging fixes per male ( $n$ = 59). Most foraging fixes were recorded during the nestling period (78\%; 46 of 59), with the remainder recorded during the incubation period $(22 \% ; 13$ of 59$)$. Foraging fixes (including general-area foraging fixes) were located a mean of $137 \mathrm{~m} \mathrm{(95 \%} \mathrm{CI} \mathrm{=} \mathrm{115-163;} \mathrm{range} \mathrm{15-399)} \mathrm{from}$ nests. Our sample sizes did not allow for robust quantitative analysis of the distance of foraging from the nest on the basis of time; qualitatively, however, we most frequently recorded foraging fixes in the immediate vicinity of nests $(<25 \mathrm{~m})$ in the early evening and at greater distances from nests as the night progressed. Gleaning prey from within live tree crowns was the most commonly observed foraging tactic by males, but we also saw owls gleaning from tree trunks, hawking between tree crowns, and ground-foraging from low (1-3 $\mathrm{m}$ high) perches.

For foraging fixes identified to specific trees $(n$ $=23$ ), the most competitive models indicated that the owls' micro-site selection was based primarily on the species of the focal tree $(E R=1.19)$ and crown volume $(E R=1.76$; Table 1$)$. While the models gave some support for the inclusion of whether the focal tree was live or dead, the ER of 0.57 indicates that this may have been a result of overfitting of the model, or that live ponderosa pines also tended to be those trees with the greatest crown volume. Trees used for foraging had a mean crown volume of $1195 \mathrm{~m}^{3}(95 \% \mathrm{CI}=890$ 1518) compared to $315 \mathrm{~m}^{3}(95 \% \mathrm{CI}=108-577)$ for available trees. Trees used for foraging were also disproportionately ponderosa pines $(61 \% ; 14$ of 23) and live (vs. dead; 91\%; 21 of 23), whereas available trees were $26 \%$ ponderosa pines ( 7 of 27 ) and $56 \%$ live (15 of 27). Models did not indicate

TABLE 1. Mixed-effects models with $\delta$ WAIC $<5$ for foraging micro-site selection by male Flammulated Owls breeding within the post-burn area of the 2002 Hayman Fire in Colorado.

\begin{tabular}{|c|c|c|c|}
\hline Model & $\delta$ WAIC & $\begin{array}{c}\text { No. of } \\
\text { effective } \\
\text { parameters }\end{array}$ & $\begin{array}{l}\text { Model } \\
\text { weight }\end{array}$ \\
\hline $\begin{array}{l}\text { Focal live/dead } \\
\quad+\text { focal species }\end{array}$ & $0.0^{a}$ & 6.8 & 0.32 \\
\hline Focal crown volume & 0.1 & 7.0 & 0.30 \\
\hline $\begin{array}{l}\text { Focal crown volume } \\
+ \text { focal species }\end{array}$ & 1.0 & 10.2 & 0.19 \\
\hline Focal species & 2.9 & 6.1 & 0.07 \\
\hline
\end{tabular}

$a$ Widely applicable information criterion $($ WAIC) $=68.5$. 
any selection based on burn severity $(\mathrm{ER}=0.04)$; mean CBIs for used and unused foraging locations were $0.78(95 \% \mathrm{CI}=0.53-1.05)$ and $0.99(95 \%$ $\mathrm{CI}=0.75-1.27$ ), respectively (both scores represent burn of low severity).

\section{DAY-Roosting HabiTaT}

Day-roosting fixes $(n=22)$ were most commonly recorded in stands burned at low severity (mean $\mathrm{CBI}=0.93$; $95 \% \mathrm{CI}=0.72-1.16$ ); only one was recorded in a stand burned at high severity (CBI $>2.0$ ). We recorded a mean of 4.4 (range $0-7$ ) day roosts per male. More day-roosting fixes were recorded during the nestling period $(77 \% ; 17$ of 22) than during the incubation period $(23 \% ; 5$ of 22). Day roosts were frequently located within $100 \mathrm{~m}$ of nest trees (mean 81; 95\% CI $=51-114$; range 3-256). Males typically perched within 1 $\mathrm{m}$ of trunks in areas surrounded by foliage within live crowns.

The most competitive models indicated that whether the roost tree was live $(E R=6.69)$ was the most important predictor of use (Table 2). Models also indicated some selection based on burn severity: CBI scores were slightly lower for day-roost sites $(0.93 ; 95 \% \mathrm{CI}=0.71-1.14)$ than for other trees available in the owls' territories $(0.99 ; 95 \%$ $\mathrm{CI}=0.69-1.14)$, although both CBIs represent low severity and the confidence intervals overlap widely. The ER for CBI was 1.22. Similarly, the models gave some support for a role of the $\mathrm{dbh}$ and height of the roost tree, though ERs for these variables were 0.41 and 0.16 , respectively. These variables' inclusion in top models may indicate overfitting of the models, or that live trees tended to have a larger $\mathrm{dbh}$ and/or be associated with lower CBIs. Trees in which owls day-roosted were disproportionately live trees $(96 \% ; 22$ of 23$)$, had an average dbh of $34.6 \mathrm{~cm}(95 \% \mathrm{CI}=29.6-39.9)$,

TABLE 2. Mixed-effects models with $\delta$ WAIC $<5$ for day-roost micro-site selection by male Flammulated Owls breeding within the post-burn area of the 2002 Hayman Fire in Colorado.

\begin{tabular}{|c|c|c|c|}
\hline Model & $\delta$ WAIC & $\begin{array}{c}\text { No. of } \\
\text { effective } \\
\text { parameters }\end{array}$ & $\begin{array}{l}\text { Model } \\
\text { weight }\end{array}$ \\
\hline Focal live/dead + CBI & $0.00^{a}$ & 6.3 & 0.45 \\
\hline Focal live/dead + focal dbh & 1.80 & 6.8 & 0.19 \\
\hline $\begin{array}{l}\text { Focal live/dead + focal } \\
\text { height }\end{array}$ & 2.60 & 6.7 & 0.12 \\
\hline Focal live/dead & 3.20 & 4.1 & 0.09 \\
\hline Focal dbh + CBI & 3.20 & 8.0 & 0.09 \\
\hline
\end{tabular}

$a$ Widely applicable information criterion $($ WAIC) $=55.0$. and an average height of $15.7 \mathrm{~m}(95 \% \mathrm{CI}=$ $14.0-17.5$ ), in comparison to $48 \%$ live (11 of $23)$, dbh of $21.7 \mathrm{~cm}(95 \% \mathrm{CI}=15.7-27.7)$, and height of $10.2 \mathrm{~m}$ (95\% CI $=7.6-12.8)$ for other available trees.

\section{DISCUSSION}

When establishing breeding territories, the Flammulated Owls we studied appeared to avoid forests burned at high severity, as home ranges of males contained less high-severity burned area and more low-severity burned or unburned area than the area within Hayman Fire's perimeter as a whole. As estimated by MCP, the sizes of the home ranges (mean 12.9 ha) we measured in this study were consistent with those reported for unburned habitats $(14.2 \pm 5.0[\mathrm{SD}]$ ha; Linkhart et al. 1998), suggesting that the unburned or lowseverity burned habitats used by owls in this study were of similar quality to those in unburned forest studied elsewhere. In addition, the proportion of home ranges burned at high severity was positively correlated with home-range size, suggesting that these high-severity burned areas represented lowquality habitat. Other studies have suggested that intraspecific differences in the sizes of birds' home ranges are inversely correlated with habitat quality (e.g., Tufto et al. 1996, Clark 2007).

In contrast to the patterns observed at the home-range scale, our findings suggest that Flammulated Owls' habitat selection at finer spatial scales (for foraging and day-roosting) does not reflect a strong preference for or avoidance of habitat on the basis of burn severity. The owls' selection patterns resembled those observed in unburned habitat (e.g., Linkhart et al. 1998). Home ranges selected by breeding birds must contain all the resources required for breeding, including habitats required at finer spatial scales (Johnson 1980). By avoiding high-severity burned forests and selecting low-severity or unburned forests at larger spatial scales, Flammulated Owls may ensure that they select home ranges containing sufficient resources for all breeding behaviors (nesting, roosting, foraging etc.). This type of spatially dynamic habitat selection, in which habitat-selection patterns at finer spatial scales are contingent upon habitat-selection decisions at broader spatial scales, has been reported across a structurally diverse spectrum of ecosystems, from grasslands (Chalfoun and Martin 2007, McNew et al. 2013) to forests (McClure et al. 2012). Overall, this strategy may reflect the owls' evolution with regimes of fires of low and mixed severity, since the responses of animals adapted to more 
severe fires should reflect a tolerance of or preference for severely burned landscapes (Hutto 2008).

The specific micro-site characteristics the Flammulated Owls we studied preferred for foraging and day-roosting indicated that the species selects habitats that contain large, old ponderosa pines with voluminous crowns, as it does in unburned forests (Linkhart et al. 1998, Linkhart and Reynolds 2006, 2007). This habitat structure is specifically created and maintained by regular low-severity fire (or the low-severity component of mixed-severity fires; Covington and Moore 1994, Veblen et al. 2000). The large trees the owls prefer for foraging may be important because they offer more prey, or because these trees may be structurally more conducive to the owls' preferred foraging tactic of sit-and-wait/gleaning. Similarly, the owls' preferred day-roosting locations may provide greater concealment which, in other owl species, has been associated with lower risks of predation and mobbing (Young et al. 1998, Sunde et al. 2003, Willey and Van Riper 2014).

Our results, combined with the fact that during our initial census of the area burned in the Hayman Fire we detected no Flammulated Owls in the largest expanses of high-severity burn, suggest that animals whose life histories are adapted to environments maintained by fires of low and/ or mixed severity may be displaced by regimes of high-severity fire. Our results are consistent with other studies showing that habitat specialists lack resilience to modification and/or fragmentation of preferred habitats (Cahill and Matthysen 2006, Owino and Ryan 2006, Mathews et al. 2014). Across the western United States, the pattern of regimes of low- and mixed-severity fire transitioning to those with much more highseverity fire (Huckaby et al. 2001, Miller and Safford 2012, Fulé et al. 2014) has significant conservation implications. Increasingly large and more severe wildfires are predicted to occur in the future (Westerling et al. 2006, Marlon et al. 2012, Sherriff et al. 2014), potentially causing extirpations of animals and modifying the distribution and composition of plant communities for decades or longer.

We observed breeding male Flammulated Owls establishing home ranges in areas burned at a lower level of severity than characteristic of the Hayman burn as a whole. It is unclear, however, if these habitats were similar enough to preferred unburned habitats, where crown volume and tree age at the scale of the home range have been strongly linked to demographic success (Linkhart and Reynolds 1997, Linkhart and Reynolds
2006), for the owl to maintain viable populations. Indeed, a dataset larger than is presented here suggests that in the area burned in the Hayman Fire males return to at least some home ranges at lower rates (Linkhart unpubl. data). This reduction may reflect either higher mortality or lower territory fidelity. Disturbance-induced demographic effects have been reported in many other studies (e.g., Robinson et al. 1995, Dugger et al. 2010), including demographic effects mediated through changes to animals' habitat-use patterns (e.g., Vanderwerf 2004). For example, fire increased the likelihood of dispersal from breeding territories and reduced survival of male Northern Spotted Owls (Strix occidentalis caurina) in California (Clark et al. 2011). Further study with samples larger than are presented here is needed for better understanding of the Flammulated Owl's demographic responses in burned landscapes and to determine whether burn severity plays a mediating role in these responses.

Given that our findings are based on only five radio-tracked Flammulated Owls in one local population, further study is needed with larger sample sizes and in disparate areas across the owl's range to clarify the generality of our results. Further study also is needed to develop a broader understanding of landscape-scale responses to modified fire regimes and climate change and to assess species' long-term responses across trophic levels, especially in other areas of forests dominated by pine. Finally, rangewide monitoring of the Flammulated Owl would be valuable in revealing population trends at landscape scales as well as how these trends correlate with broad-scale changes in ecosystem processes such as wildfire.

\section{ACKNOWLEDGMENTS}

This project was made possible with funding and equipment from a Howard Hughes Undergraduate Research Grant, the Colorado College Venture Grant Committee, Colorado College Department of Biology, Jackson Fellowship Program of the Hulbert Center for Southwest Studies at Colorado College, several generous private donors, and the U.S. Department of Agiculture's (USDA) Forest Service. Many people assisted in locating territories and nests of owls as well as the quantification of nest sites: Quintana Baker, Kirsten Becker, Connor Blanchet, Ross Calhoun, Sophia Chudacoff, Max Ciaglo, Cat Couhuette, Robbie de Burlo, Mathew Dickinson, Erin Evers, Dashielle Fierabend, Jennifer Gillespie, John Gioia, Bailey Griscom, Bryan Grundy, Dakin Henderson, Collin Knauss, Lisi Lohre, Alex Mattes-Ritz, Julie 
Megler, Eric Monk, Eric Palm, Phoebe ParkerShames, Mark Parlier, Jayne Reynolds, Ellen Rigell, Saraya Ruano, Paul Shauwecker, Jaclyn Silsby, Makendra Silverman, Nick Stephens, Julia Varnergardner, Charles Wilder, Alice Winters, Mel Wright, and Katie Zaidel. The USDA Forest Service's Rocky Mountain Research Station kindly provided living and working quarters in the Manitou Experimental Forest. We thank Peter Brown, Markus Mika, and Colleen Handel for their very helpful reviews of the manuscript.

\section{LiTERATURE CITED}

Abella, S. R., Covington, W. W., Fulé, P. Z., Lentile, L. B., Sánchez Meador, A. J., and Morgan, P. 2007. Past, present, and future old growth in frequent-fire conifer forests of the western United States. Ecol. Soc. 12(2): article 16; doi 10.5751/ES-02171120216.

Allen, C. D., Betancourt, J. L., and Swetnam, T. W. 1998. Landscape changes in the southwestern United States: Techniques, long-term datasets, and trends, in Perspectives on the land use history of North America: A context for understanding our changing environment (T. D. Sisk, ed.), pp. 71-84. Biol. Sci. Rep. USGS/BRD/BSR-1998-003. U.S. Geological Survey, Lafayette, LA; landcover.usgs. gov/luhna/chap9.php.

Allen, C. D., Savage, M., Falk, D. A., Suckling, K. F., Swetnam, T. W., Schulke, T., Stacey, P., Morgan, P. B., et al. 2002. Ecological restoration of southwestern ponderosa pine ecosystems: A broad perspective. Ecol. Appl. 12:1418-1433; doi 10.1890/1051-0761 (2002)012[1418:EROSPP]2.0.CO;2.

Beyer, H. L. 2012. Geospatial Modelling Environment, version 0.7.2.1; www.spatialecology.com/gme.

Bibby, C. J., Burgess, N. D., and Hill, D. A. 1997. Bird Census Techniques. Harcourt Brace, San Diego.

Binkley, D., Sisk, T., Chambers, C., Springer, J., and Block, W. 2007. The role of old-growth forests in frequent-fire landscapes. Ecol. Soc. 12(2): article 18; doi 10.5751/ES-02170-120218.

Brawn, J. D., and Balda, R. P. 1988. The influence of silvicultural activity on ponderosa pine forest bird communities in the southwestern United States, in Bird Conservation 3 (J. A. Jackson, ed.), pp. 3-21. Univ. of Wisconsin Press, Madison, WI.

Breininger, D. R., Larson, V. L., Duncan, B. W., Smith, R. B., Oddy, D. M., and Goodchild, M. F. 1994. Landscape patterns of Florida Scrub Jay habitat use and demographic success. Conserv. Biol. 9:14421453; doi 10.1046/j.1523-1739.1995.09061442.x.

Brown, P. M., and Shepperd, W. D. 2001. Fire history and fire climatology along a $5^{\circ}$ gradient in latitude in Colorado and Wyoming, USA. Paleobotanist 50:133-140; www.rmtrr.org/data/ Brown\&Shepperd_2001.pdf.

Brown, P. M., Kaufmann, M. R., and Shepperd, W.
D. 1999. Long-term, landscape patterns of past fire events in a montane ponderosa pine forest of central Colorado. Landscape Ecol. 14:513-532; doi 10.1023/A:1008137005355.

Cahill, J. R. A., and Matthysen, E. 2006. Habitat use by two specialist birds in high-Andean Polylepis forests. Biol. Conserv. 140:62-69; doi 10.1016/j.biocon.2007.07.022.

Chalfoun A. D., and Martin, T. E. 2007. Assessments of habitat preferences and quality depend on spatial scale and metrics of fitness. J. Appl. Ecol. 44:983992; doi 10.1111/j.1365-2664.2007.01352.x.

Clark, D. A. 2007. Demography and habitat selection of Northern Spotted Owls in post-fire landscapes of southwestern Oregon. M.S. thesis, Oregon State Univ., Corvallis.

Clark, D. A., Anthony, R. G., and Andrews L. S. 2011. Survival rates of Northern Spotted Owls in postfire landscapes of southwest Oregon. J. Raptor Res. 45:38-47; doi 10.3356/JRR-10-42.1.

Conway, C. J., and Kirkpatrick, C. 2007. Effect of forest fire suppression on Buff-breasted Flycatchers. J. Wildl. Mgmt. 71:445-457; doi 10.2193/2005-755.

Committee on the Status of Endangered Wildlife in Canada (COSEWIC). 2010. COSEWIC assessment and update status report on the Flammulated Owl Otus flammeolus in Canada. COSEWIC, Ottawa; www.registrelep-sararegistry.gc.ca/document/ default_e.cfm?documentID $=2011$.

Cottam, G., and Curtis, J. T. 1956. The use of distance measures in phytosociological sampling. Ecology 37:451-460; doi 10.2307/1930167.

Covington, W. W., and Moore, M. M. 1992. Post-settlement changes in natural disturbance regimes: Implications for restoration of old-growth ponderosa pine ecosystems, in Old-growth forests in the Southwest and Rocky Mountain regions; Proceedings of a workshop (M. R. Kaufmann, W. H. Moir, and W. H. Bassett, tech. eds.), pp. 81-99. Gen. Tech. Rep. RM-213. USDA For. Serv., Rocky Mountain For. Range Exp. Stn., Fort Collins, CO; www.fs.fed.us/ $\mathrm{rm} /$ pubs_series $/ \mathrm{rm} / \mathrm{gtr} / \mathrm{rm} \_$gtr213.pdf.

Covington, W. W., and Moore, M. M. 1994. Southwestern ponderosa forest structure: Changes since Euro-American settlement. J. For. 92:39-47.

Davis, R. S., Hood, S., and Bentz, B. J. 2012. Fire-injured ponderosa pine provide a pulsed resource for bark beetles. Can. J. For. Res. 42:2022-2036; doi 10.1139/x2012-147.

Delignette-Muller, M. L., and Dutang, C. 2015. fitdistrplus: An R package for fitting distributions. J. Stat. Software 64:1-34; www.jstatsoft.org/v64/i04/.

Donovan, T. M., Beardmore, C. J., Bonter, D. N., Brawn, J. D., Cooper, R. J., Fitzgerald, J., Ford, R., Gauthreaux, S. A., et al. 2002. Priority research needs for the conservation of Neotropical migrant landbirds. J. Field Ornithol. 73:329-339; doi 10.1648/0273-8570-73.4.329.

Dugger, K. M., Ainley, D. G., Lyver, P. O’B., Barton, K., and Ballard, G. 2010. Survival differences and 
the effect of environmental instability on breeding dispersal in an Adelie Penguin meta-population. Proc. Natl. Acad. Sci. USA 107:12375-12380; doi 10.1073/pnas.1000623107.

Environmental Systems Research Institute (ESRI). 2012. ArcGIS Release 10.1. Redlands, CA.

Fagan, W. F., Cantrell, R. S., and Cosner, C. 1998. How habitat edges change species interactions. Am. Nat. 153:165-182; doi 10.1086/303162.

Finney, M. A., McHugh, C. W., Bartlette, R., Close, K., and Langowski, P. 2003. Fire behavior, fuel treatments, and fire suppression on the Hayman Fire. Part 2: Description and interpretations of fire behavior, in Hayman Fire case study (R. T. Graham, tech. ed.), pp. 59-95. Gen. Tech. Rep. RMRSGTR-114. USDA For. Serv., Rocky Mountain Res. Stn., Fort Collins, CO; www.fs.usda.gov/treesearch/ pubs/28714.

Fulé, P. Z., Crouse, J. E., Heinlein, T. A., Moore, M. M., Covington, W. W., and Verkamp, G. 2003. Mixed-severity fire regime in a high-elevation forest of Grand Canyon, Arizona, USA. Landscape Ecol. 18:465-486; doi 10.1023/A:1026012118011.

Fulé, P. Z., Swetnam, T. W., Brown, P. M., Falk, D. A., Peterson, D. L., Allen, C. D., Aplet, G. H., Battaglia, M. A., et al. 2014. Unsupported inferences of high-severity fire in historical dry forests of the western United States: Response to Williams and Baker. Global Ecol. Biogeogr. 23:825-830; doi 10.1111/ geb. 12152 .

Graham, R. T. (tech. ed.). 2003. Hayman Fire case study. Gen. Tech. Rep. RMRS-GTR-114. USDA For. Serv., Rocky Mountain Res. Stn., Fort Collins, CO; www.fs.fed.us/rm/pubs/rmrs_gtr114.pdf.

Hinde, A. 1956. The biological significance of the territories of birds. Ibis 98:340-369; doi 10.1111/j.1474919X.1956.tb01419.x.

Horne, J. S., and Garton, E. O. 2006. Likelihood cross-validation versus least squares cross-validation for choosing the smoothing parameter in kernel home-range analysis. J. Wildl. Mgmt. 70:641-648; doi 10.2193/ 0022-541X(2006)70[641:LCVLSC]2.0.CO;2.

Huckaby, L. S., Kaufmann, M. R., Stoker, J. M., and Fornwalt, P. J. 2001. Landscape patterns of montane forest age structure relative to fire history at Cheedman Lake in the Colorado Front Range, in Ponderosa pine ecosystem restoration and conservation: Steps toward stewardship (R. K. Vance, C. B. Edminster, B. Carleton, W. W. Covington, and J. A. Blake, compilers), pp. 19-27. Proceedings RMRS-P-22. USDA For. Serv., Rocky Mountain Res. Stn., Fort Collins, CO; www.fs.usda.gov/treesearch/pubs/46667.

Hurteau, M. D., Bradford, J. B., Fulé, P. Z., Taylor, A. H., and Martin, K. L. 2014. Climate change, fire management, and ecological services in the southwestern US. For. Ecol. Mgmt. 327:280-289; doi 10.1016/j.foreco.2013.08.007.

Hutto, R. L. 2008. The ecological importance of severe wildfires: Some like it hot. Ecol. Appl. 18:18271834; doi 10.1890/08-0895.1.
Intergovernmental Panel on Climate Change (IPCC). 2013. Climate Change 2013: The Physical Science Basis. Contribution of Working Group I to the Fifth Assessment Report of the Intergovernmental Panel on Climate Change (T. F. Stocker, D. Qin, G.-K. Plattner, M. Tignor, S. K. Allen, J. Boschung, A. Nauels, Y. Xia, et al., eds.). Cambridge Univ. Press, New York, NY; www.ipcc.ch/report/ar5/wg1/.

Johnson, D. H. 1980. The comparison of usage and availability measurements for evaluating resource preference. Ecology 6:65-71; doi 10.2307/1937156.

Kaufmann, M. R., Fornwalt, P. J., Huckaby, L. S., and Stoker, J. M. 2001. Cheesman Lake - A historical ponderosa pine landscape guiding restoration in the South Platte watershed of the Colorado Front Range, in Ponderosa pine ecosystem restoration and conservation: Steps toward stewardship (R. K. Vance, C. B. Edminster, B. Carleton, W. W. Covington, and J. A. Blake, compilers), pp. 9-18. Proceedings RMRS-P-22. USDA For. Serv., Rocky Mountain Res. Stn., Fort Collins, CO; www.fs.usda.gov/treesearch/pubs/46666.

Kaufmann, M. R., Huckaby, L. S., Fornwalt, P. J., Stoker, J. M., and Romme, W. H. 2003. Using tree recruitment patterns and fire history to guide restoration of an unlogged ponderosa pine/Douglas-fir landscape in the southern Rocky Mountains after a century of fire suppression. Forestry 76:231-241; doi 10.1093/forestry/76.2.231.

Key, C. H., and Benson, N. C. 2006. Landscape assessment (LA): Sampling and analysis methods, in FIREMON: Fire Effects Monitoring and Inventory System (D. C. Lutes, tech. ed.), pp. LA-1 to LA-55. Gen. Tech. Rep. RMRS-GTR-164-CD. USDA For. Serv., Rocky Mountain Res. Stn., Fort Collins, CO; www.fs.usda.gov/treesearch/pubs/24066.

Kotliar, N. B., Kennedy, P. L., and Ferree, K. 2007. Avifaunal responses to fire in the southwestern montane forests along a burn severity gradient. Ecol. Appl. 17:491-507; doi 10.1890/06-0253.

Linkhart, B. D., and McCallum, D. A. 2013. Flammulated Owl (Psiloscops flammeolus), in The Birds of North America Online (A. Poole, ed.), no. 93. Cornell Lab Ornithol., Ithaca, NY; doi 10.2173/bna93.

Linkhart, B. D., and Reynolds, R. T. 1997. Territories of Flammulated Owls (Otus flammeolus): Is occupancy a measure of habitat quality?, in Biology and conservation of owls of the Northern Hemisphere (J. R. Duncan, D. H. Johnson, and T. H. Nicholls, eds.), pp. 226-230. Gen. Tech. Rep. NC-190. USDA For. Serv., North Central Exp. Stn., St. Paul, MN; www.fs.usda.gov/treesearch/pubs/15492.

Linkhart, B. D., and Reynolds, R. T. 2006. Lifetime reproduction of Flammulated Owls in Colorado. J. Raptor Res.40:29-37; doi 10.3356/0892-1016(2006)40[29: LROFOI]2.0.CO;2.

Linkhart, B. D., and Reynolds, R. T. 2007. Return rate, fidelity, and dispersal in a breeding population of Flammulated Owls (Otus flammeolus). Auk 124:264275; doi 10.1642/0004-8038(2007)124[264:RRFADI]2.0.CO;2. 
Linkhart, B. D., Reynolds, R. T., and Ryder, R. A. 1998. Home range and habitat use of breeding Flammulated Owls in Colorado. Wilson Bull. 110:342-351.

Linkhart, B. D., Fox, J. W., and Yanco, S. W. 2016. Migration timing and routes, and wintering areas of Flammulated Owls. J. Field Ornithol. 87:42-54; doi 10.1111/jofo. 12136 .

Marlon, J. R., Bartlein, P. J., Gavin, D. G., Long, C. J., Anderson, R. S., Briles, C. E., Brown, K. J., Colombaroli, D., et al. 2012. Long-term perspective on wildfires in the western USA. Proc. Natl. Acad. Sci. USA 109:E535-E543; doi 10.1073/pnas.1112839109.

Mathews, T. J., Cottee-Jones, H. E., and Whittaker, R. J. 2014. Habitat fragmentation and the species-area relationship: A focus on total species richness obscures the impact of habitat loss on habitat specialists. Diversity Distrib. 20:1136-1146; doi 10.1111/ ddi. 12227.

Mawson, J. C., Thomas, J. W., and DeGraaf, R. M. 1976. Program HTVOL: The determination of tree crown volume by layers. Res. Pap. NE-354. USDA For. Serv., Northeastern For. Exp. Stn., Upper Darby, PA; www.fs.usda.gov/treesearch/pubs/14463.

McClure, C. J. W., Rolek, B. W., and Hill, G. E. 2012. Predicting occupancy of wintering migratory birds: Is microhabitat information necessary? Condor 144:482-490; doi 10.1525/cond.2012.110139.

McNew, L. B., Gregory, A. J., and Sandercock, B. K. 2013. Spatial heterogeneity in habitat selection: Nest site selection by Greater Prairie-Chickens. J. Wildl. Mgmt. 77:791-801; doi 10.1002/jwmg.493.

Miller, J. D., and Safford, H. 2012. Trends in wildfire severity: 1984 to 2010 in the Sierra Nevada, Modoc Plateau, and southern Cascades, California, USA. Fire Ecol. 8:41-57; doi 10.4996/fireecology.0803041.

Miller, J. D., Safford, H. D., Crimmins, M., and Thode, A. E. 2009. Quantitative evidence of increasing forest fire severity in the Sierra Nevada and southern Cascade Mountains, California and Nevada, USA. Ecosystems 12:16-32; doi 10.1007/s10021-0089201-9.

National Oceanic and Atmospheric Administration (NOAA). 2010. Normals Annual/Seasonal for Cheesman,CO,StationID:GHCND:USC00051528; www.ncdc.noaa.gov/cdo-web/datasets/normal_ann/ stations/GHCND:USC00051528/detail (accessed 16 March 2015).

Odion, D. C., Hanson, C. T., Arsenault, A., Baker, W. L., DellaSala, D. A., Hutto, R. L., Klenner, W., Moritz, M. A., et al. 2014. Examining historical and current mixedseverity fire regimes in ponderosa pine and mixed-conifer forests of western North America. PLoS One 9(2): e87852; doi 10.1371/journal.pone.0087852.

Owino, A. O., and Ryan, P. G. 2006. Habitat associations of papyrus specialist birds at three papyrus swamps in western Kenya. Afr. J. Ecol. 44:438-443; doi 10.1111/j.1365-2028.2006.00652.x.

R Core Team. 2014. R: A language environment for statistical computing. R Foundation for Statistical Computing, Vienna, Austria; www.R-project.org/.

Reynolds, R. T., and Linkhart, B. D. 1984. Methods and materials for capturing and monitoring Flammulated Owls. Great Basin Nat. 44:49-51.

Robinson, S. K., Thompson, F. R., III, Donovan, T. M., Whitehead, D. R., and Faaborg, J. 1995. Regional forest fragmentation and the nesting success of migratory birds. Science 267:1987-1990; doi 10.1126/science.267.5206.1987.

Rocca, M. E., Brown, P. M., MacDonald, L. H., and Carrico, C. M. 2014. Climate change impacts on fire regimes and key ecosystem services in Rocky Mountain forests. For. Ecol. Mgmt. 327:290-305; doi $10.1016 / \mathrm{j} /$ foreco.2014.04.005.

Romme, W. H., Veblen, T. T., Kaufmann, M. R., Sherriff, R., and Regan, C. M. 2003. Ecological effects of the Hayman fire; Part 1: Historical (pre-1860) and current (1860-2002) fire regimes, in Hayman Fire case study (R. T. Graham, tech. ed.). Gen. Tech. Rep. RMRS-GTR-114. USDA For. Serv., Rocky Mountain Res. Stn., Fort Collins, CO; www.fs.usda. gov/treesearch/pubs/28729.

Running, S. W. 2006. Is global warming causing more, larger wildfires? Science 313:927-928; doi 10.1126/ science. 1130370 .

Schmitz, O. J., Beckerman, A. P., and O’Brien, K. M. 1997. Behaviorally mediated trophic cascades: Effects of predation risk on food web interactions. Ecology 78:1388-1399; doi 10.1890/0012-9658(1997) 078[1388:BMTCEO]2.0.CO;2.

Schoennagel, T., Veblen, T. T., and Romme, W. H. 2004. The interaction of fire, fuels, and climate across Rocky Mountain forests. BioScience 54:661-676; doi 10.1641/0006-3568(2004)054[0661:TIOFFA] 2.0.CO;2.

Sherriff, R. L., Platt, R. V., Veblen, T. T., Schoennagel, T. L., and Gartner, M. H. 2014. Historical, observed, and modeled wildfire severity in montane forests of the Colorado Front Range. PLoS One 9(9): e106971; doi 10.1371/journal.pone.0106971.

Sunde, P., Bølstad, M. S., and Desfor, K. B. 2003. Diurnal exposure as a risk sensitive behavior in Tawny Owls Strix aluco? J. Avian Biol. 34:409-418; doi 10.1111/j.0908-8857.2003.03105.x.

Szaro, R. C., and Balda, R. P. 1982. Selection and monitoring of avian indicator species: An example from a ponderosa pine forest in the southwest. Gen. Tech. Rep. RM-GTR-89. USDA For. Serv., Rocky Mountain For. Range Exp. Stn., Fort Collins, CO; archive.org/details/IND82087483.

Tufto, J., Anderson, R., and Linnell, J. 1996. Habitat use and ecological correlates of home range size in a small cervid: The roe deer. J. Anim. Ecol. 65:715724; doi 10.2307/5670.

U.S. General Accounting Office (USGAO). 1999. Western National Forests: A cohesive strategy is needed to address catastrophic wildfire threats. GAO/RCED99-65; www.gao.gov/archive/1999/rc99065.pdf. 
U.S. Fish and Wildlife Service (USFWS). 2008. Birds of Conservation Concern 2008. U.S. Dept. Inter. Fish and Wildl. Serv., Div. Migratory Bird Mgmt., Arlington, VA; www.fws.gov/migratorybirds/pdf/ grants/BirdsofConservationConcern2008.pdf.

U.S. Forest Service (USFS). 2004. Forest Service Sensitive Species that are not listed or proposed under the ESA; www.fs.fed.us/biology/resources/pubs/tes/ fs_ss_1dec04.pdf.

Vanderwerf, E. A. 2004. Demography of Hawai' i 'Elepaio: Variation with habitat disturbance and population density. Ecology 85:770-783; doi 10.1890/02-0668.

Veblen, T. T., Kitzberger, T., and Donnegan, J. 2000. Climatic and human influences on fire regimes in ponderosa pine forests in the Colorado Front Range. Ecol. Appl. 40:1178-1195; doi 10.1890/1051-0761 (2000)010[1178:CAHIOF]2.0.CO;2.

Wantanabe, S. 2010. Asymptotic equivalence of Bayes cross validation and widely applicable information criterion in singular learning theory. J. Mach.Learn. Res. 11:3571-3594.

Westerling, A. L., Hidalgo, H. G., Cayan, D. R., and Swetnam, T. W. 2006. Warming and earlier spring increase western U.S. forest wildfire activity. Science 313:940-943; doi 10.1126/science.1128834.
Westerling, A. L., Turner, M. G., Smithwick, E. A. H., Romme, W. H., and Ryan, M. G. 2011. Continued warming could transform Greater Yellowstone fire regimes by mid-21st century. Proc. Natl. Acad. Sci. USA 108:13165-13170; doi 10.1073/ pnas. 1110199108.

Western Regional Climate Center (WRCC). 2015. Cheesman, Colorado (051528), period of record monthly climate summary-precipitation; www. wrcc.dri.edu/cgi-bin/cliMAIN.pl?.co1528.

Willey, D., and Van Riper, C., III, 2014. Home range characteristics of Mexican Spotted Owls in the Rincon Mountains, Arizona. Wilson J. Ornithol. 126:5359; doi 10.3356/0892-1016(2007)41[10:HRCOM S]2.0.CO;2.

Williams, M. A., and Baker, W. L. 2012. Spatially extensive reconstructions show variable-severity fire and heterogeneous structure in historical western United States dry forests. Global Ecol. Biogeogr. 21:10421052; doi 10.1111/j.1466-8238.2011.00750.x.

Young, K. E., Valdez, R., Zwank, P. J., and Gould, W. R. 1998. Density and roost site characteristics of Spotted Owls in the Sierra Madre Occidental, Chihuahua, Mexico. Condor 100:732-736. 